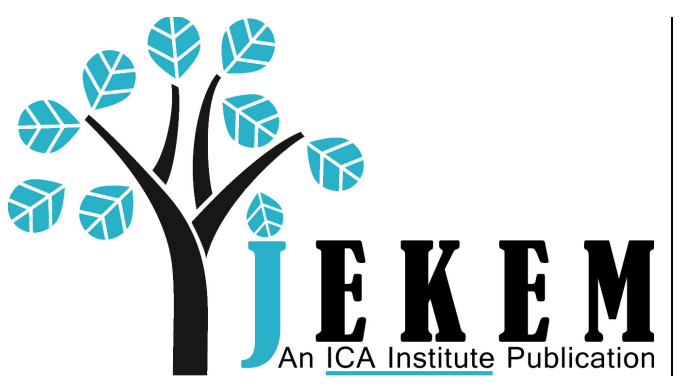

India, China ANd America Institute

1549 ClaIRMONT ROAD, SUITE 202 • DECATUR, GA 30033 USA

WWW.ICAINSTITUTE.ORG

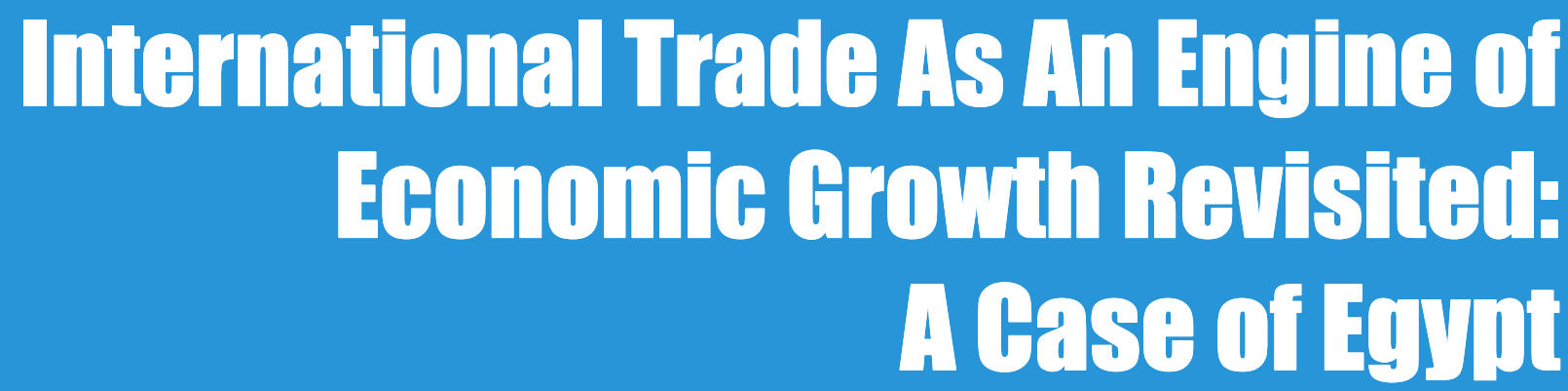

Galen Smith \& Kishore G. Kulkarni

Journal of Emerging Knowledge on Emerging Markets

Volume 2

November 2010 


\section{International Trade As An Engine of Economic Growth Revisited: A Case of Egypt}

Galen Smith University of Denver

Kishore G. Kulkarni Metropolitan State College of Denver

Journal of Emerging Knowledge on Emerging Markets

Volume 2

November 2010

$\mathrm{T}$

he promotion of free trade is one of the oldest policy implications offered by international economic theory. While significant disconnects have historically existed between the politics and the economics of trade policy, the rapid economic growth experienced by the export-oriented Asian countries during the 1960s and 1970s amidst a largely stagnating and trade-restrictive developing world provided a precedent for effective development policy, especially within the world's less developed countries (LDCs). Free trade arguments have since been championed by a majority of global institutions, including the International Monetary Fund (IMF hereafter), the International Bank for Reconstruction and Development (IBRD) or World Bank, the Organization for Economic Co-operation and Development (OECD hereafter), and the World Trade Organization (WTO hereafter). The argument goes that a reduction in trade barriers will induce greater economic efficiency within LDCs by offering cheaper world prices to domestic consumers (increasing consumer welfare) while creating conditions of competition for domestic producers (forcing domestic production to shift towards the most efficient sectors based upon availability of domestic factors). 


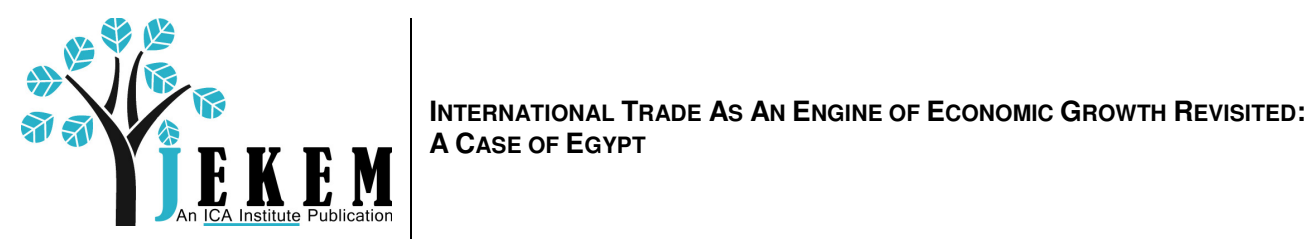

Egypt represents a striking example of an LDC that has recently transitioned from a closed to an open economy in the hopes of creating conditions for increased economic development. Since embarking upon a campaign of neoliberal reforms during the early 1990s, Egypt has slashed its average tariff rates from $>30 \%$ to $6.4 \%$, with additional nontariff barriers also experiencing significant reductions. ${ }^{1}$ It may come as no surprise that Egypt has also made some of the most significant strides in increasing economic growth, effectively doubling its percentages of real GDP growth (3.2\% to 6\%) and nominal GDP/capita growth $(\$ 1,197$ to $\$ 2,652)$ since trade barriers were aggressively eliminated in 2002. ${ }^{2}$ Such preliminary evidence seems to support the common assumption that trade liberalization promotes economic growth.

Yet correlation does not imply causation, a truism that necessarily provokes the need for a deeper understanding of Egypt's experience with liberalization and growth. This paper attempts to critically examine the connection between trade openness and growth through a comprehensive analysis of economic liberalization in Egypt over the last decade. The necessity of such an inquiry rests in the realization that growth is an aggregation of many economic factors, none of which can be held constant if the sum is to be properly understood. This paper will attempt to argue that trade liberalization, despite paralleling economic growth increases, cannot be conclusively observed as a causal influence of economic growth in Egypt.

\section{Section I: History}

An examination of trade liberalization in Egypt requires a brief historical survey of Egypt's protectionist past. The military coup of 1952 brought Gamal Abdal Nasser to political power over a largely agrarian Egyptian state tied economically, politically, and socially to the liberal traditions of Great Britain. Nasser quickly gained widespread popular support through his promises of severing imperial influence through the expansion of industry within the economy, social justice and democracy within the political system, and Arab nationalism throughout the region. The realization of economic and political transformation began in 1956 when land reforms were initiated to transfer private land from the elites to the general population. This was followed by nationalization of all banks and foreign firms, as well as the Suez Canal. With the economy effectively nationalized by 1959 , Nasser proceeded with the first industrial five-year plan, which was designed to stimulate growth and modernize Egypt. By the time the Egyptian economy began to experience economic shortfall in the late 1960s, Nasser's Egyptian Socialist Party (ESP) had assumed authoritarian control over 75 percent of industrial output and 90 percent of all new investment in industry. ${ }^{3}$

\footnotetext{
${ }^{1}$ Economist Intelligence Unit. “Country Commerce: Egypt.” Economist Intelligence Unit, New York, NY, (2008).

${ }^{2}$ International Monetary Fund. "IMF Data Mapper.” http://www.imf.org/external/datamapper/index.php.

${ }^{3}$ Iliya Harik, Economic Policy Reform in Egypt (Jacksonville: University of Florida Press, 1997): p. 18.
} 
Anwar Sadat inherited the stagnating Egyptian state in 1971, and made an early realization that liberal reform was an economic necessity. Yet, many scholars have argued that Sadat's economic opening did little more than turn Egypt into a rentier economy, dependent upon oil, remittances, tourism, and foreign aid. The existence of such rents provided the capital necessary to maintain trade barriers for domestic industry and subsidies for overpriced consumer goods. Hosni Mubarak took the presidential helm in 1981 following the assassination of Sadat, and continued to oppose liberalization despite increasing levels of inflation and foreign debt. This strategy induced near economic collapse when the Gulf War severed Egypt from two of its prized sectors, tourism and Gulf remittances.

With economic options shrinking before their eyes, the Egyptian government sought the help of the IMF in 1991. The resulting agreement, Egypt's Reform and Structural Adjustment Program (ERSAP), awarded Egypt an 18-month loan worth 278 million SDR (special drawing rights) contingent upon the adoption of neoliberal reforms to help create macroeconomic stability. Egypt had great success with the reforms, registering one of the largest fiscal adjustments to date. The government also attempted limited privatization by putting 314 public companies up for sale in an effort to thin the state apparatus. The financial sector also experienced reforms, with interest rate ceilings removed in an effort to battle inflation. Trade liberalization represented one of the few issues mostly unaddressed by the Egyptian state during this period of reform. While tariff ranges were reduced from $10-80 \%$ to $5-40 \%$ percent, the system remained significantly constrained by excessive nontariff barriers. ${ }^{4}$

The issue of trade openness entered the limelight in 2001 when the government "declared export expansion to be a matter of life and death." The Economist Intelligence Unit observes that aggressive measures were taken beginning in 2004 to strip trade barriers from the Egyptian economy, with the official tariff rate reduced from $14.6 \%$ to $9 \%$ on around 6,500 imported items. In an effort to aid domestic industry, customs ceilings were reduced from $104 \%$ to $40 \%$, with duties halved for raw materials and completely eliminated for machinery. ${ }^{6}$ Egypt's notoriously oppressive system of procedures and contracts were simplified during this time as well, reducing storage time for imported goods from 28 days to two days. ${ }^{7}$ Further measures were taken in 2007 to reduce the weighted tariff average on imports from $9 \%$ to $6.9 \% .^{8}$ Egypt has received international praise for the above-mentioned efforts and has been awarded top-10 global reformer honors in the World Bank's Doing

${ }^{4}$ Gouda Abdel-Khalek, Stabilization and Adjustment in Egypt: Reform or De-Industrialization? (United Kingdom: Fondazione Eni Enrico Mattei, 2001): p. 56.

${ }^{5}$ Economist Intelligence Unit, "Country Commerce: Egypt,” p. 92.

${ }^{6}$ United States Trade Representative, "Trade Summary: Egypt," United States Trade Representative, 2008.

http://www.ustr.gov/assets/Document_Library/Reports_Publications/2008/2008_NTE_Report/asset_uplo ad_file288_14647.pdf.

${ }^{7}$ Economist Intelligence Unit, "Country Commerce: Egypt,” p. 92.

${ }^{8}$ United States Trade Representative, "Trade Summary." 


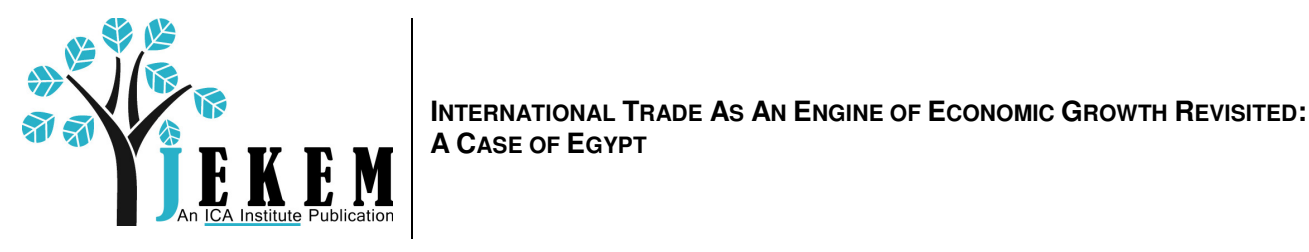

Business Report three of the last four years, which was propelled largely by its trade rank improvement from $83^{\text {rd }}$ to $24^{\text {th }}$ in the world (now ahead of such countries as the United Kingdom, Taiwan, and Luxembourg). ${ }^{9}$ Such improvements are significant, considering the fact that the WTO viewed Egypt's tariff system as "complex" and displaying "high effective protection" in $2005 .^{10}$

\section{Section II: Theory}

The positive relationship between trade liberalization and growth was embedded within theoretical assumption for nearly the first two hundred years of classical economic theory. The question that was often addressed was "how can a country benefit from trade?" While the answers provided by Adam Smith (1776), David Ricardo (1817), Eli Heckscher and Bertil Ohlin (1911), and Paul Samuelson (1936) varied considerably, each of them elevated free trade to the realm of assumption, alongside perfectly competitive markets and similar demand preferences. While few countries have ever approached free trade perfectly, Paul Krugman and Maurice Obstfeld explain that free trade was nonetheless advocated as an "ideal toward which trade policy should strive."11

Trade liberalization represents the ideal policy prescription because the economic benefits of free trade are relatively easy to illustrate (see Figure 1). Countries are generally confronted with two prices for a good within the global economy: the domestic price and the world price. If the world price (P2) is lower than the domestic price (P1), then domestic consumers will purchase the good at an increased equilibrium quantity, shown in Figure 1 at point Q4. The imposition of an import tax (tariff) by the domestic government will increase the world price of a good by a certain amount, resulting in price P3. This imposition will increase government revenue by the product of total imports following the tariff (Q3 - Q2) and the difference between world price (P2) and world price + tariff (P3). Domestic producers will also benefit since the world price + tariff allows for a shift in domestic production from Q1 to Q2 at a higher price. Yet these increases will come at a comparatively larger loss to consumer surplus, since all consumers are forced to pay a higher price for the good being taxed, resulting in a total welfare loss of the two DWL triangles in Figure 1.

\footnotetext{
${ }^{9}$ World Bank, "Doing Business 2009: Comparing Regulation in 181," International Bank for Reconstruction/World Bank, 2009. http://www.doingbusiness.org/Documents/FullReport/2009/DB_2009_English.pdf.

${ }^{10}$ WTO Secretariat, "Trade Policy Review Egypt: Report by the Secretariat," World Trade Organization WT/TRP/S/150, 28 June 2005, p. viii.

${ }^{11}$ Paul Krugman and Maurice Obstfeld, International Economics: Theory and Policy, $5^{\text {th }}$ Edition (New York: Addison-Wesley, 2000): p. 218.
} 
Figure 1: Effect of Tariffs on Welfare

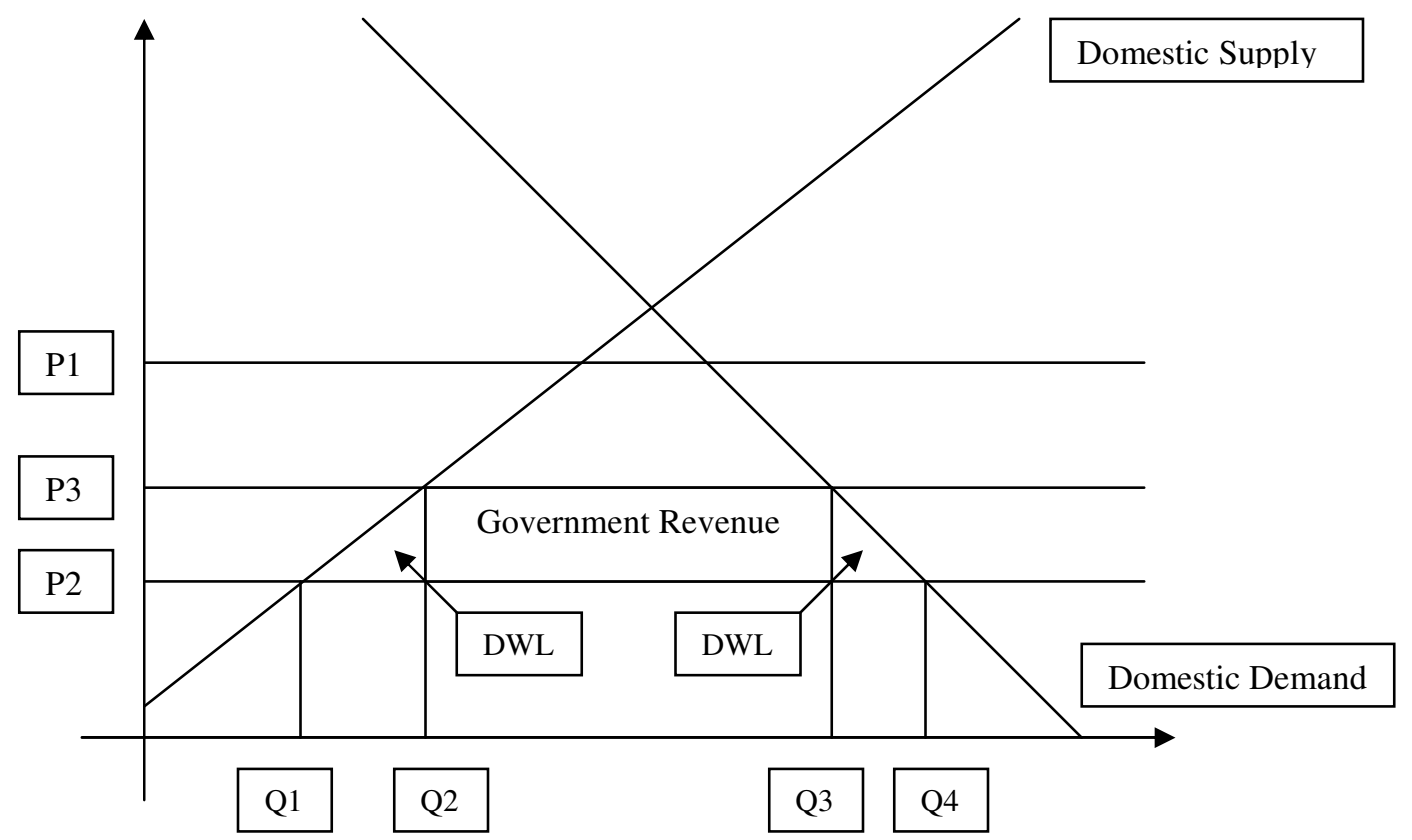

In addition to the assertion that free trade best promotes the efficient allocation of resources, free trade has also been argued to create additional long-run benefits such as economies of scale, growth externalities through technology transfer, and increased productivity as prices for intermediate goods decrease. Economies of scale refer to industries that require a very large volume of production before the lowest average cost (AC) is reached. Rudiger Dornbush explains that such industries are unlikely to arise in an environment of trade protection based on the fact that such industries require large markets to be efficient, which often escape the closed economy which is more concerned with domestic consumption. ${ }^{12}$ Growth externalities refer to the production benefits that may result from the incorporation of new technologies received through increased interaction with foreign countries. Therefore, "'free trade' offers more opportunities for learning and innovation than are provided by a system of 'managed' trade." 13 Finally, Paul Romer (1989) has argued that free trade allows for a greater variety of intermediate inputs to enter the market, potentially expanding an LDC's production possibility curve through the influx of capital goods used for assembly production.

Despite free trade producing numerous theoretical benefits, economists have highlighted several reasons why free trade may not be a desirable policy including: the prevalence of market failures, the need to support infant industries, and political risk.

\footnotetext{
${ }^{12}$ Rudiger Dornbush, "The Case for Trade Liberalization in Developing Countries," Journal of Economic Perspectives, Vol. 6, No. 1 (1992): pp. 73-77.

${ }^{13}$ Krugman, International Economics: p. 219.
} 


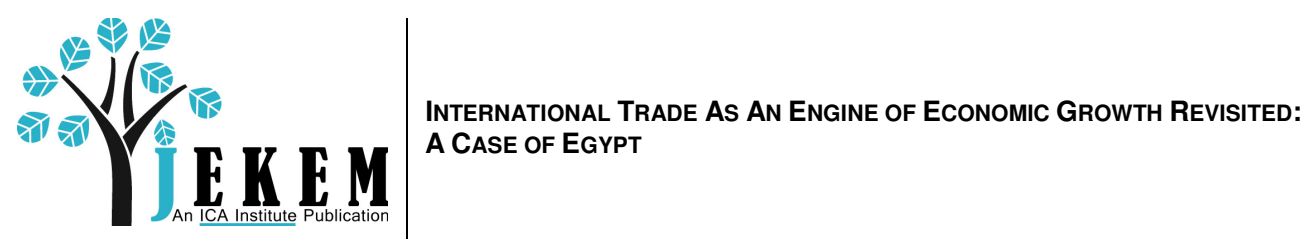

Krugman effectively theorizes the market failure argument, stating that a "hands-off policy is desirable (free trade) in any one market only if all other markets are working properly. If they are not working properly, a government intervention, which appears to distort incentives in one market, may actually increase welfare by offsetting the consequences of market failures elsewhere" (emphasis mine). ${ }^{14}$ Krugman uses the example that an economically inefficient subsidy for labor-intensive industries may reap large social rewards if unemployment is high. ${ }^{15}$ Dani Rodrik offers the example that Brazil could potentially benefit from tax increases if the increased revenue is funneled into investment projects that yield returns larger than the initial loss in consumer surplus caused by the tax. ${ }^{16}$ The logic behind this approach is one of "second-best," accepting that government intervention is necessary based on the reality that domestic economies can never be free of imperfections.

The infant industry argument revolves around the idea that trade protection is necessary in order to grant domestic industries adequate time to develop prior to competing with more mature industries in more developed countries (MDCs). Such ideas inspired the import-substitution industrialization (ISI) policies of the 1950s and 1960s that combined heavy trade protection and exchange rate controls in order to provide cheap capital imports to domestic industries. A prolonged critique of ISI would be superfluous, considering it has been, for the most part, universally discredited. Nevertheless, the infant industry has remained widely discussed, due to the huge successes of the export-focused economies of East and Southeast Asian. By encouraging heavily protected industries to produce for world markets, the Asian economies have avoided the moral hazard problem that plagued domestic-oriented industries in countries that supported ISI. A final argument for trade protection arises through politics. While this aspect will not be examined further, it is nonetheless important to mention that trade policy cannot be detached from the political process (particularly in societies with highly influential interest groups).

\section{Section III: Literature Review}

This paper will address two different sets of literature, with the first including the recent empirical work addressing the relationship between trade openness and economic growth, and the second covering the recent literature on Egypt's liberalization experience since the IMF-sponsored structural adjustment program in 1992. Robert Baldwin's "Openness and Growth" offers the most recent and comprehensive survey of the literature

\footnotetext{
${ }^{14}$ Ibid: p. 225.

15 Ibid.

${ }^{16}$ Ricardo Hausmann, Dani Rodrik, and Andres Velasco, “Growth Diagnostics," NBER Working Paper (2005). http://ksghome.harvard.edu/ drodrik/growth_accelerations_aug05.pdf. For an abbreviated version, check Ricardo Hausmann, Dani Rodrik and Andres Velasco, "Getting the Diagnosis Right," Finance and Development, Vol. 43, No. 1 (2006), http://www.imf.org/external/pubs/ft/fandd/2006/03/hausmann.htm.
} 
on the empirical relationship between openness and growth. ${ }^{17}$ Baldwin observes that such literature has grown immensely since the 1970s for two reasons: (1) free trade arguments found few followers during the heavily protectionist interwar and post-colonial periods, and (2) the simultaneous failure of ISI and success of export-oriented Asian economies set the stage for a reassessment of free trade. Baldwin identifies the first wave of studies as mostly econometric, with Balassa $(1971,1978)$ being one of the first to find a positive relationship between trade openness and growth. These studies were supported by other prominent scholars, including Krueger (1978) and Bhagwati (1978). While the above works observed a positive relationship between trade openness and growth, Baldwin mentions that many of these scholars qualified their findings with the concession that factors promoting growth proved numerous, complicating the process of isolating the trade/growth relationship. Criticisms eventually emerged from Edwards (1993) and Srinivasan and Bhagwati (2001), effectively discrediting the early econometric approaches.

The current debate now involves what Baldwin terms "sophisticated cross-country studies."18 One such study was conducted by Dollar (1992), which concluded that trade distortions combined with exchange rate volatility led to lower per capita GDP levels. ${ }^{19}$ Easterly $(1989,1993)$ found that trade protection has an adverse effect on capital accumulation, which is likely to hamper economic growth. ${ }^{20}$ Sachs and Warner (1995) offer one of the most robust studies to date. After controlling for relatively few variables and adding complexity to the liberalization process (by distinguishing five kinds of trade barriers), they find that a positive and significant correlation exists between openness and growth. Frankel and Romer (1999) add geography into the equation, concluding that trade openness and growth are positively correlated in regions with higher country densities.

The strongest critique to the above positions has been offered by Rodriguez and Rodrik (2001). From the outset, Rodriguez and Rodrik highlight the important distinction between 'export levels vs. growth' and 'openness vs. growth.' Their analysis concludes that a strong correlation does in fact exist between export increases and growth, but that the connection between openness and growth remains "fragile". ${ }^{21}$ Even pro-trade scholars such as Krueger (1978) have conceded that the openness-growth connection is plagued by ambiguity due to the multitude of factors that can account for growth. This tenuous connection has been further emphasized in studies that have shown that trade openness can have a negative effect on growth in certain circumstances. Rodriguez and Rodrik explain that "Grossman and Helpman (1991), Feenstra (1990), Matsuyama (1992), and others have

\footnotetext{
${ }^{17}$ Robert Baldwin, "Openness and Growth: What's the Empirical Relationship?" NBER Working Paper 9578 (Cambridge, Mass: National Bureau of Economic Research, 2003): pp. 1-34.

${ }^{18}$ Ibid: p. 18.

${ }^{19}$ Ibid: p. 19.

${ }^{20}$ James Cassing and Stephen Tokarick, "Trade and Growth in the Presence of Distortions," IMF Working Paper WP/05/12, (January 2005): p. 3.

${ }^{21}$ Francisco Rodriquez and Dani Rodrik, "Trade Policy and Economic Growth: A Skeptic's Guide to the Cross-National Evidence," in Ben Bernanke and Kenneth Rogoff, NBER Macroeconomics Annual 2000 (Cambridge), 2001: pp. 315.
} 


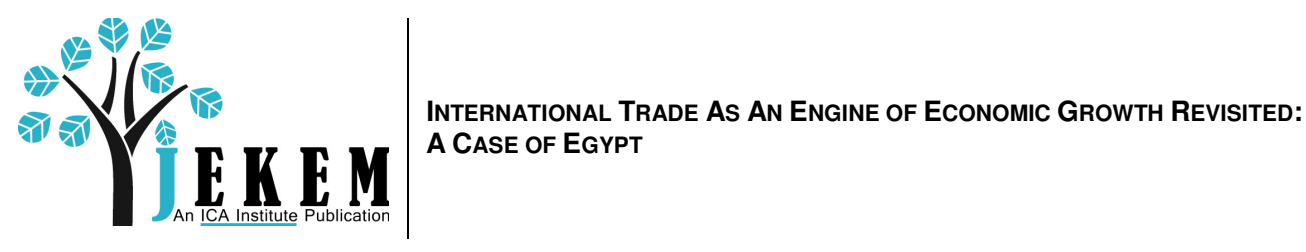

worked out examples where a country that is behind in technological development can be driven by trade to specialize in traditional goods and experience a reduction in its long-run rate of growth." ${ }^{22}$ Rodrik (2008) concludes elsewhere that restrictive trade policies often receive the brunt of international criticism, when the "true culprits [of poor growth] are ineffective institutions, geographic determinants, or inappropriate macroeconomic policies." 23

The literature on Egypt's experience with economic liberalization can be temporally divided between the period of structural adjustment and the period of liberalization following adjustment. Scholars that have been fascinated by Egypt's experience with structural adjustment include Harik (1997), Richards and Waterbury (2008), Subramanian (1997), Zaki (2001), Abdel-Khalek (2001), and Adams Jr. (2000). These scholars all argue that structural adjustment offered numerous economic benefits, and helped Egypt exit a very precarious economic situation in which the twin deficits of trade and government debt were astronomical. These authors seem less inclined to comment on the future of liberalization, but instead simply emphasize the economic necessity for reform that emerged in the early 1990s.

The majority of the scholarship on post-adjustment in Egypt has focused upon the successes of economic liberalization. On the issue of trade, Galal and Lawrence (1997, 2005) argue that Egypt's performance in reducing tariffs warrants a free-trade agreement with the United States. Madani and Olarreaga (2002) take a more tentative position, arguing that trade protection remains a deeply nested aspect of the Egyptian political economy. Soderling (2005) claims that trade relations may be a more significant problem than trade restrictions, arguing that Egypt should move away from its inefficient trade relationship with the United States and focus more upon developing relations with the European Union. Omran (2007) and Ford (2008) observe that Egypt's financial sector has been one of the fastest growing in the world, offering powerful new avenues for investment. Applications of the binding constraints approach articulated by Rodrik, Hausmann, and Velasco (2005) have been undertaken by Dobronogov and Iqbal (2005) and Enders (2007), with the former concluding that Egypt is prepared to explore new avenues of financing development from abroad while the latter contends that the low appropriability of returns caused by macroeconomic inefficiency and corruption remain primary concerns.

While many aspects of Egypt's liberalization experience have been examined, there has not been a detailed understanding of trade openness and its relationship to growth. Dobroganov and Iqbal (2005) and Enders (2007) approach policy prescriptions that address trade openness, but choose not to explicitly highlight trade liberalization as a primary engine for economic development. This paper will hopefully explain such a gap in the

\footnotetext{
${ }^{22}$ Ibid, p. 269.

${ }^{23}$ Dani Rodrik, "Trading in Illustions." The Economic Development Reader. Ed. Giorgio Secondi (London: Routledge, 2008): p. 464.
} 
literature by highlighting the complexity inherent to the openness-growth debate in the case of Egypt.

\section{Section IV: Methodology}

The following case study will proceed in two parts. The first part will isolate growth statistics and trade barrier levels in an effort to observe the existing correlation between growth and trade openness. This is important in order to initially approach the relationship in question. The second part will reintroduce alternative growth variables such as foreign direct investment (FDI) and financial liberalization. The intent of this move is to acknowledge the complexity in determining influences of economic growth. If trade openness has had a dramatic impact upon Egypt's economic growth, the factors of FDI and financial liberalization must be shown to have minimal influence. It should be noted that this paper does not attempt to approach the openness-growth relationship in a mathematically complex way - rather, it is intended to offer a surface-level case-study analysis that is digestible for the average reader. Yet, such reliance upon observation and description should in no way diminish the analytical conclusions of this work. The hope is that this approach simply offers a different kind of knowledge that can supplement crosscountry econometric models that construct complexity upon a foundation of oversimplification.

\section{Section V: Evidence on Openness and Growth}

The charts below differently illustrate the relationship between trade liberalization and real GDP growth in Egypt. Figure 2 compares simple average tariffs to real GDP growth. Unfortunately, gaps exist in the available data at the WTO, but it appears that a general trend can be observed of diminishing trade barriers amidst rising growth rates. Figure 3 offers a comparison between weighted tariff averages (ratio of total tariff revenue and total value of imports) and real GDP growth. While the data set is slightly incomplete, a similar relationship can be distinguished between declining weighted tariff levels and increasing real GDP growth over the time in question. 


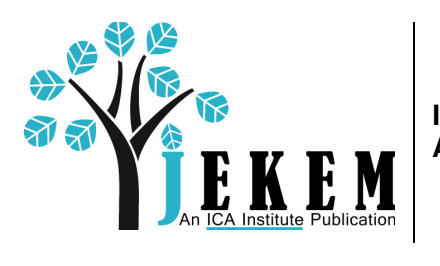

INTERnational Trade As An EngINe of Economic Growth ReVISITED: A CASE OF EGYPT
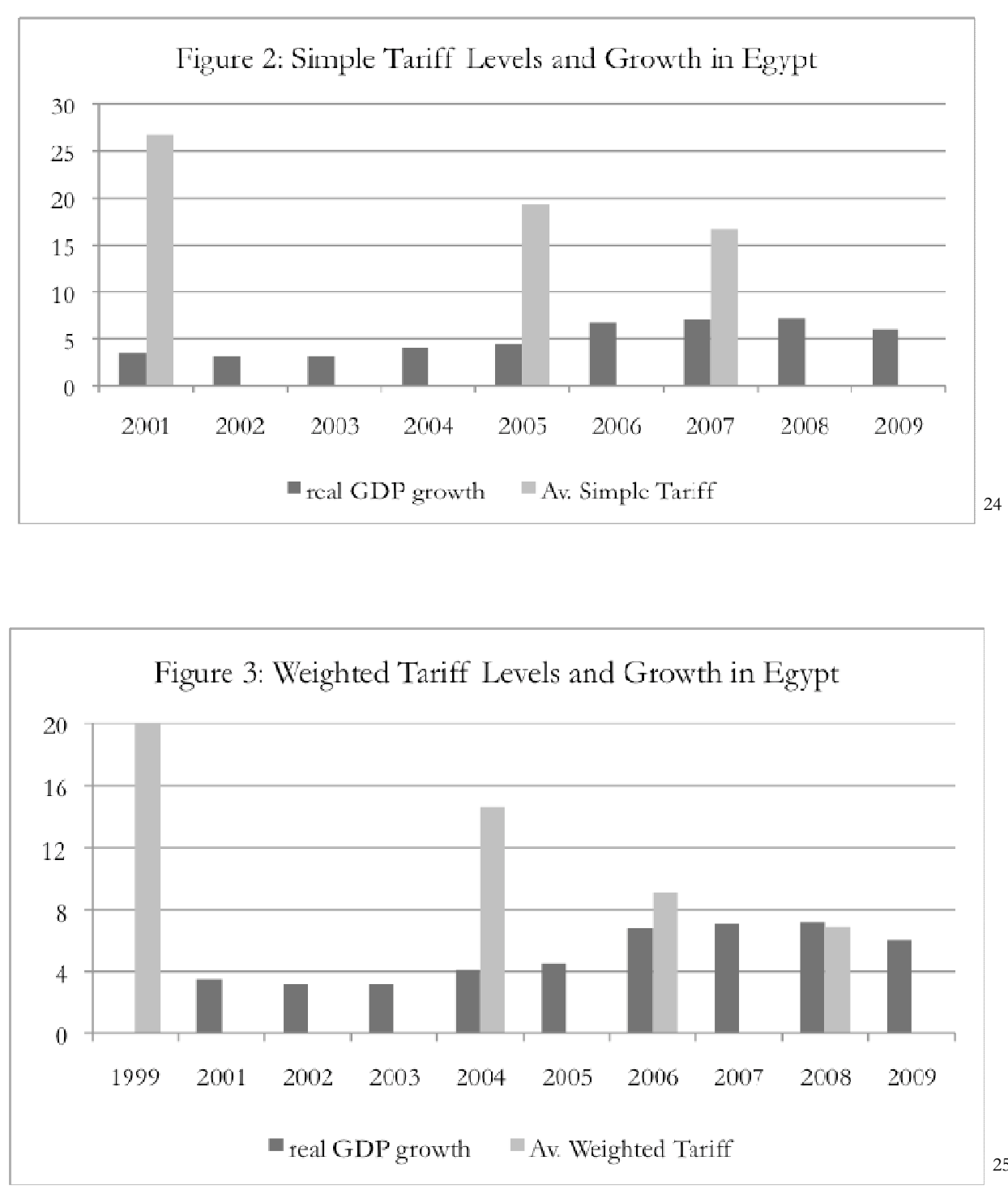

Figure 4 illustrates the relationship between real GDP growth and the Heritage Foundation's trade openness ranking, which is a composite score between 0 and 100 based on weighted tariff averages and non-tariff barriers (NTBs). ${ }^{26}$ The graph indicates that trade openness remained fairly static during Egypt's most pronounced period of real GDP growth (2003-2007). Such data can only suggest a mild to insubstantial relationship between trade openness and growth.

\footnotetext{
${ }^{24}$ Data was obtained from WTO Secretariat reports and the Economist Intelligence Unit.

${ }^{25}$ Data was obtained by successive reports provided by the United States Trade Representative and the Economist Intelligence Unit, United States Trade Representative, “Trade Summary,” 2005-2008.

${ }^{26}$ The Heritage Foundation, "Methodology for the 10 Economic Freedoms. http://www.heritage.org/index/PDF/Index09_Methodology.pdf.
} 


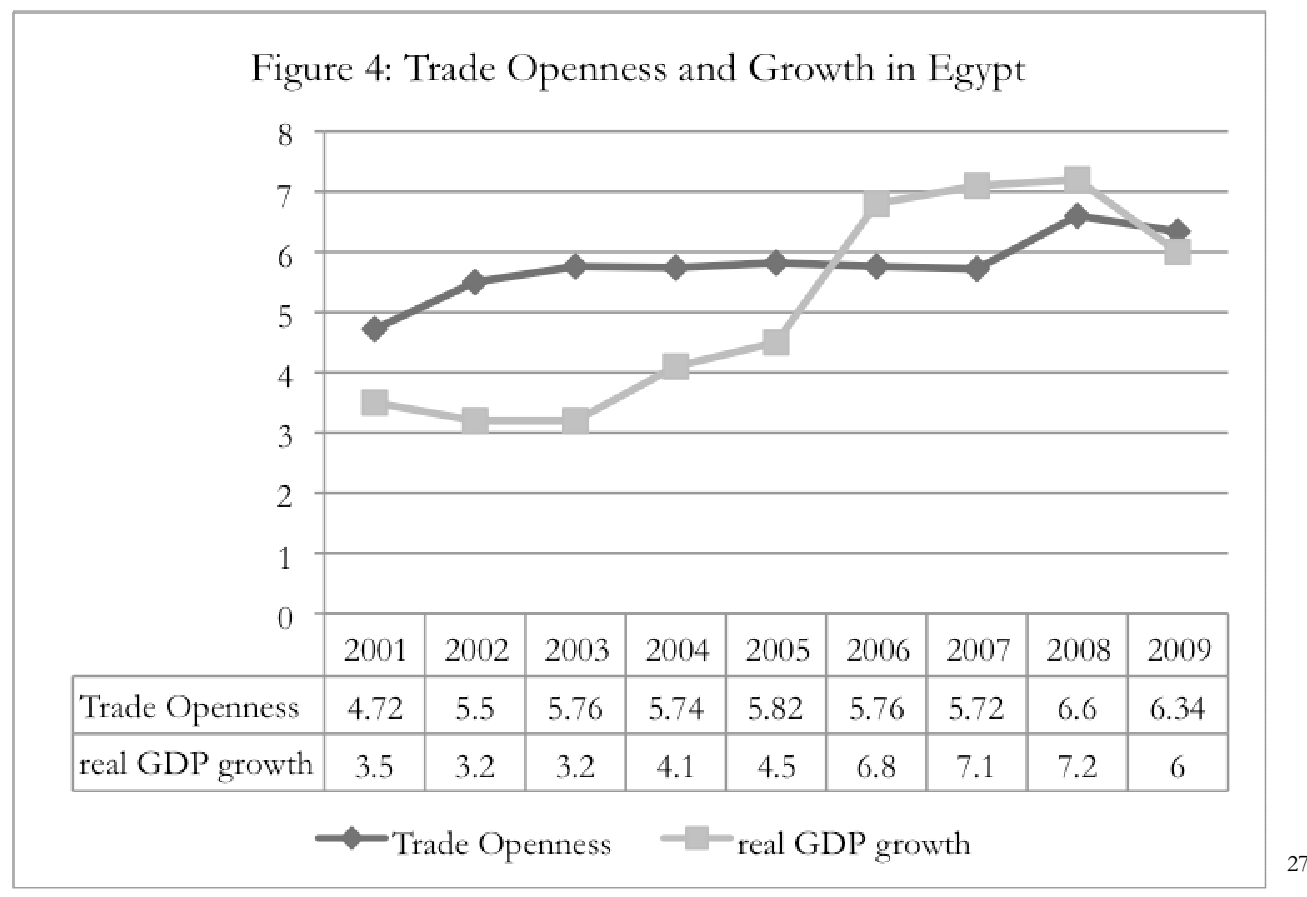

Figure 5 presents the connection between real GDP growth and the World Bank's "trading across borders" rank, which is assigned to each country based on the combination of additional costs and total delays that accrue during the transit of an average good. ${ }^{28}$ Unfortunately, the World Bank only began ranking this category in 2006, so the dataset is extremely limited. While it may prove useful in the future, the given chart shows that real GDP growth has declined as trade openness has increased. Considering the fact that the World Bank's Doing Business Rank and the Heritage Foundation's “trade openness" score are somewhat subjective measures, it remains significant that the Figure's 2 and 3 illustrate a positive relationship between tariff reduction and growth increases, since tariff levels are much more quantifiable measurements.

${ }^{27}$ It should be noted that the Doing Business Rank has been multiplied by a factor of 0.1 in order to condense data points. Data compiled from successive years of the Doing Business Report, with the most recent data in World Bank. "Doing Business 2009: Comparing Regulation in 181 Economies." International Bank for Reconstruction/World Bank, 2009: p. 101.

${ }^{28}$ World Bank, "Trading Across Borders Methodology." http://www.doingbusiness.org/MethodologySurveys/TradingAcrossBorders.aspx. 


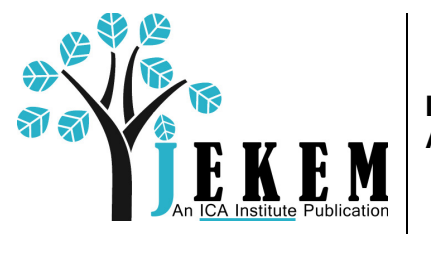

International Trade As An Engine of Economic Growth ReVisited: A CASE OF EGYPT

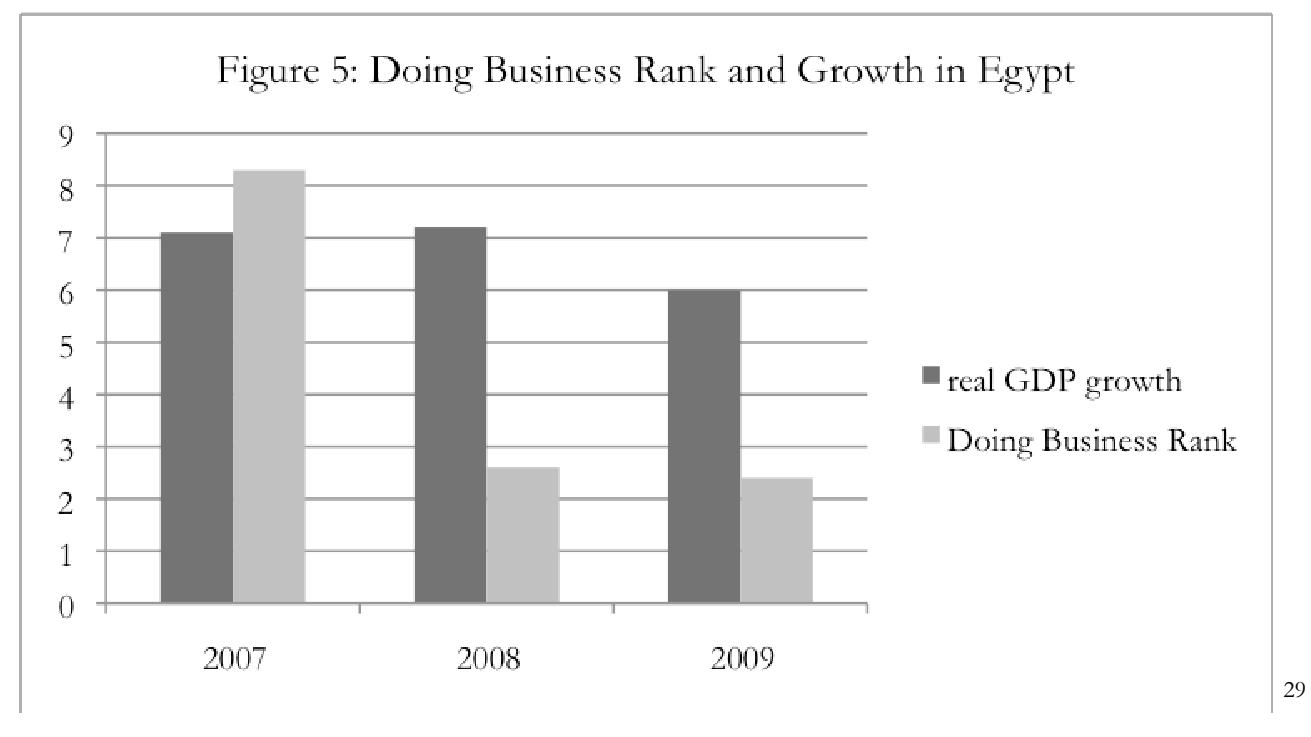

\section{Section VI: Alternative Factors}

The following pages will briefly address other possible factors that could have contributed to growth in Egypt between 2002 and 2008, including foreign direct investment (FDI), financial market expansion, and privatization. FDI, referring mainly to fixed capital inflows in the form of foreign businesses and infrastructure, has been a highly important (and controversial) factor for LDC development over the last four decades (that has not depended upon an open trade regime). Krugman and Obstfeld observe that rapid growth in Thailand during the 1990s occurred despite heavy trade barriers, likely due to Thailand's ability to attract foreign businesses to help establish productive export outlets. ${ }^{30}$ IMF data show that China's rapid growth during the 1990s paralleled an increase in FDI from $\$ 3.5$ billion to nearly $\$ 40$ billion annually, offering further evidence for FDI's potential influence on growth. Figure 6 indicates that Egypt's growth at the beginning of the $21^{\text {st }}$ century corresponds closely with substantial increases in FDI from $\$ 1$ billion to $\$ 10$ billion annually over the course of three years. Considering the fact that Egypt's total exports in 2006 amounted to just over $\$ 35$ billion, it is clear that the influx of FDI was highly significant. While portfolio investment registered minimal increases over the same period of time, it is a significant observable due to Egypt's past inability to bring in any foreign investment. Both FDI and portfolio investment help to increase the stock of capital in a domestic economy, and thereby create investment opportunities that can stimulate growth.

\footnotetext{
${ }^{29}$ It should be noted that the Heritage Foundation trade openness score has been multiplied by a factor of 0.1 for the purposes of providing effective graphic interpretation (since real GDP growth is generally always within 0 and 10. Heritage Foundation. "The 2009 Index of Economic Freedom." Heritage Foundation and Wall Street Journal, 2009. http://www.heritage.org/index/.

${ }^{30}$ Krugman, International Economics, p. 268.
} 


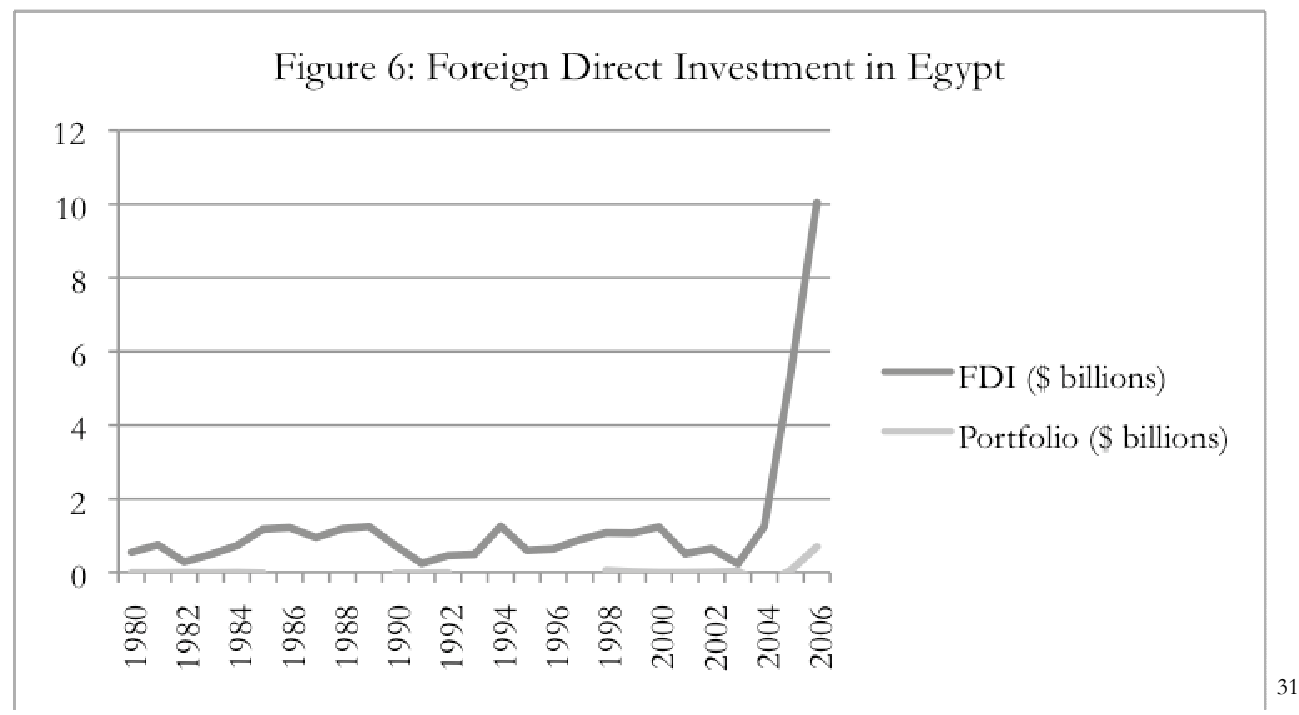

Financial markets are another effective medium for capital mobilization and increased investment. If a country can successfully establish a credible stock market where money can freely flow through the economy, domestic businesses have increased opportunities to fund investment projects that can create growth. As can be seen below in Figure 6, the Egyptian stock market soared between 2003 and 2007 (years which correspond with an increase in real GDP growth from 3.2\% to 7.1\%). The crash of the CASE 30 in 2007 also parallels a slight decline in GDP growth in Egypt (projected to be $6 \%$ in 2009), further linking financial performance and growth levels. Additional financial reforms occurred in the banking sector, with two of the four major state-owned banks privatized in 2005. Such reforms have provided additional capital opportunities for individuals and businesses that previously had to work within the inefficiencies of the state credit system.

Finally, trade volume data further complicates the positive relationship between trade openness and growth. Considering the fact that export increases have been shown to correspond closely with positive growth, the hope would be that trade liberalization would stimulate an increase in exports. Unfortunately, as can be seen in Figure 8, while total exports have increased quite significantly over the last four years, exports as a share of total GDP have actually declined slightly, from $34 \%$ to $30 \%$. This indicates that exports are growing slightly slower than the entire economy, which offers evidence that other factors must have significantly contributed to Egypt's recent episode of growth.

${ }^{31}$ IMF, "IMF Data Mapper." 

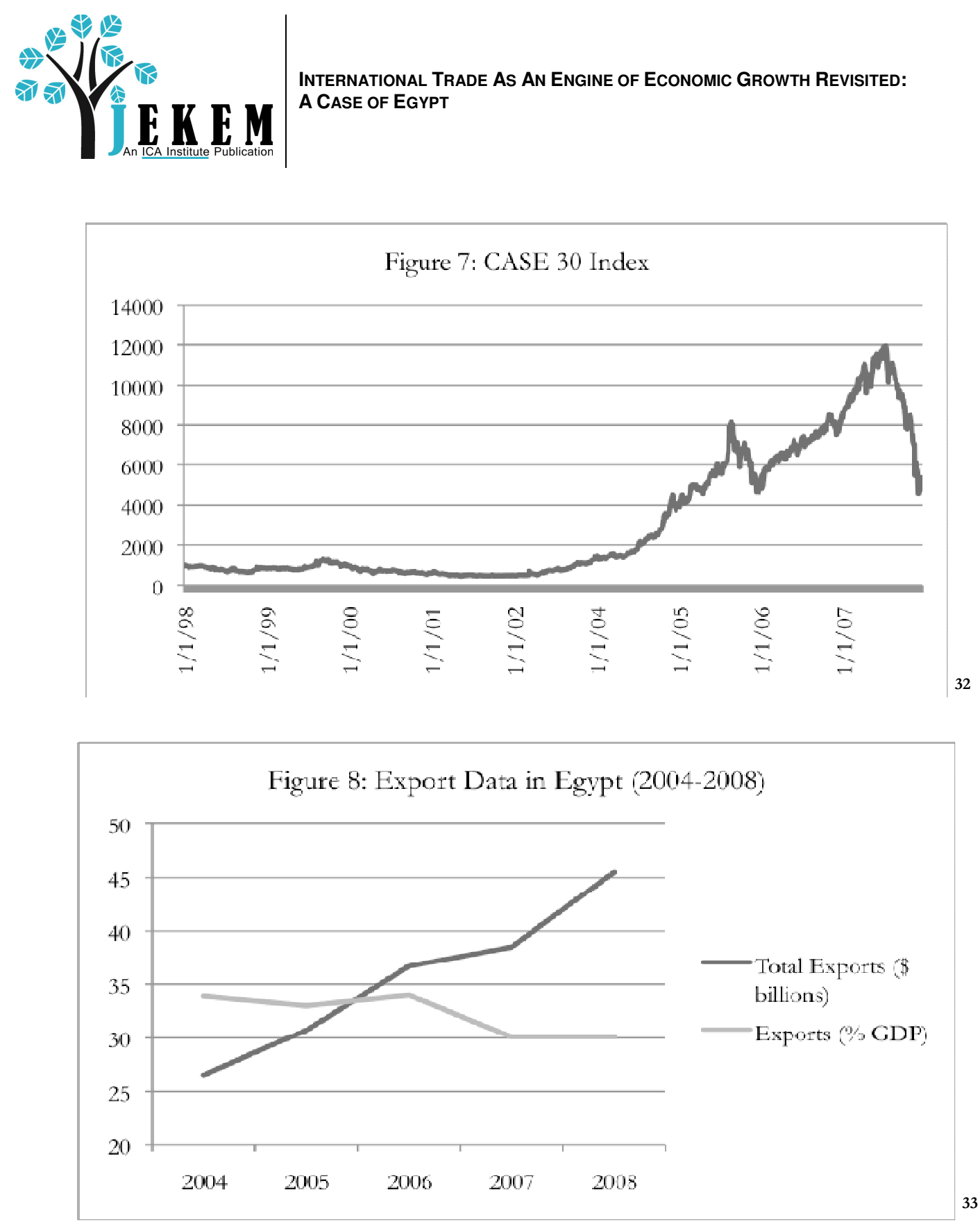

If anything has likely responded to the recent trade liberalization in Egypt, it has been import volume. Egypt has been plagued by trade deficits since its initial liberalization campaign in the 1970s eventually led to a trade deficit that exceeded $100 \%$ of GDP. While structural adjustment during the 1990s virtually eliminated the trade imbalance, it appears to be increasing once again in response to the falling barriers. So far this deficit has been compensated for by other factors, but it remains disconcerting that trade liberalization has influenced imports more than exports, considering that exports have been a factor closely correlated with increased growth. Figure 9 offers a look at Egypt's trade balance, which has gone increasingly negative since 2003 , when a trade surplus was actually attained.

\footnotetext{
${ }^{32}$ Egyptian Stock Exchange, http://www.egyptse.com/index.asp?CurPage=CASE_30_Data1M.asp.

${ }^{33}$ IMF, "IMF Data Mapper."
} 


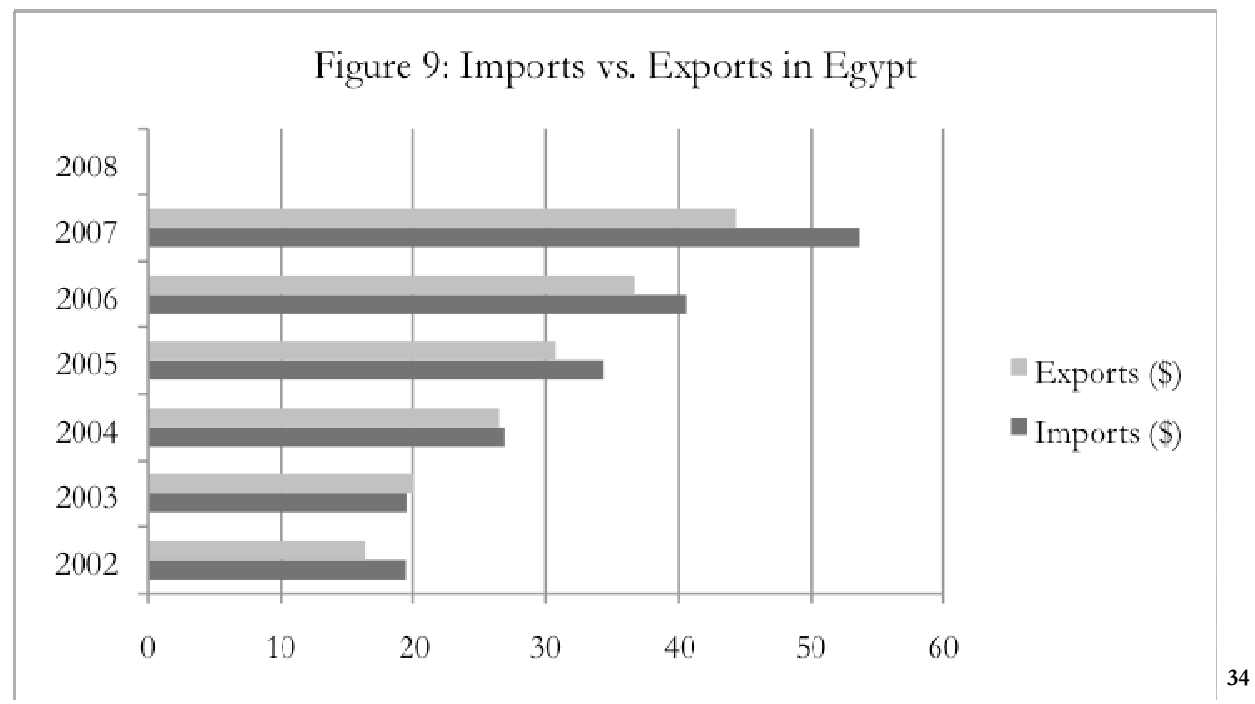

\section{Section VII: Conclusion and Summary}

The benefits of free trade are self-evident within a theoretical model of the world economy. Yet, based on the fact that economists continue to debate the practical benefits of free trade, it is clear that there still exists a disconnect between the real world and the theoretical model. This paper has attempted to contribute to this debate by focusing exclusively on Egypt. When all other variables are held constant, the positive relationship between growth and various trade openness measures appears to exist. It was shown that the tariff/growth relationship demonstrated a positive trend, while the more subjective openness/growth relationship proved inconclusive. The relative ambiguity of these trends is made more apparent following the reintroduction of alternative growth factors such as FDI and financial liberalization. Both of these factors clearly influenced economic growth during the same period of time that trade was liberalized, thus complicating the ability to observe causal impact. Additionally, trade liberalization appears to have promoted imports more than exports in Egypt - a result that runs counter to the export/growth relationship that has shown great success in East and Southeast Asia.

It should be stated that this paper is not intended to stand as a critique of free trade policies. Free trade certainly exists as an important piece to the puzzle of economic growth. The challenge is determining how big that piece actually is. Until more advanced models and a more complete understanding can be reached, LDCs will likely continue to grow in second-best ways, the reality being that all economies are more imperfect than perfect. Does this mean that free trade should not be advocated? The proper answer would likely be

\footnotetext{
${ }^{34}$ Ibid.
} 


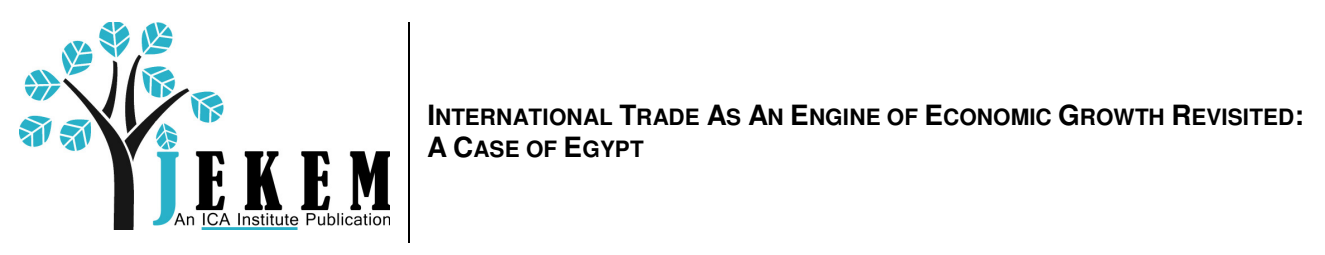

the classically indeterminate "it depends." Considering that the benefits of free trade can be numerous, especially if government intervention in the economy is limited, it is safe to say that free trade, despite its ambiguous link with economic growth in LDCs, can still be a long-term "ideal toward which trade policy should strive." 35

\section{Bibliography and References}

Abdel-Khalek, Gouda. Stabilization and Adjustment in Egypt: Reform or DeIndustrialization? United Kingdom: Fondazione Eni Enrico Mattei, 2001.

Adams Jr., Richard H. “Evaluating Development, 1980-97.” in M. Riad El-Ghonemy. Egypt in the Twenty-First Century: Challenges for development. New York: Routledge, 2003.

Baldwin, Robert. "Openness and Growth: What's the Empirical Relationship?" NBER Working Paper 9578. Cambridge, Mass: National Bureau of Economic Research, 2003: 134.

Batson, Andrew et. al. "Politics and Economics: Egypt Sees China Replacing U.S. as Top Trade Partner by 2012.” Wall Street Journal, September 7, 2006.

Cassing, James and Stephen Tokarick. "Trade and Growth in the Presence of Distortions." IMF Working Paper WP/05/12, January 2005.

Dobronogov, Anton and Farrukh Iqbal. "Economic Growth in Egypt: Constraints and Determinants." World Bank Middle East and North Africa Working Paper Series, No. 42, October 2005.

Dollar, David. "Outward-oriented Developing Economies Really Do Grow More Rapidly: Evidence from 95 LDCs, 1976-1985." Economic Development and Cultural Change, Vol. 40, No. 3, 1992: 523-544.

Dornbush, Rudiger. "The Case for Trade Liberalization in Developing Countries." Journal of Economic Perspectives, Vol. 6, No. 1, 1992: pp. 69-85.

Economist Intelligence Unit. “Country Commerce: Egypt.” Economist Intelligence Unit. United Kingdom, 2008.

Edwards, Sebastian. "Openness, Trade Liberalization, and Growth in Developing Countries.” Journal of Economic Literature, Vol. 31, September 1993: pp. 1358-1393.

Enders, Klaus. "Searching For Binding Constraints on Growth." IMF Working Paper: Middle East and Central Asia Department, 2007.

Ford, Neil. "Egyptian Banking Sector Confidence Soars.” Middle East (November 2007).

\footnotetext{
${ }^{35}$ Krugman, International Economics, p. 218.
} 
Frankel, Jeffrey and David Romer. "Does Trade Cause Growth?" American Economic Review, Vol. 89, No. 3, 1999: 379-399.

Galal, Ahmed and Robert Z. Lawrence. "Anchoring Reform with a US-Egypt Free Trade Agreement.” Institute for International Economics, Policy Analysis 74, May 2005.

Harik, Illiya. Economic Policy Reform in Egypt. Jacksonville: University of Florida Press, 1997.

Hausmann, Ricardo, Dani Rodrik and Andres Velasco. "Getting the Diagnosis Right." Finance and Development, Vol. 43, No. 1, 2006. http://www.imf.org/external/pubs/ft/fandd/2006/03/hausmann.htm.

Hausmann, Ricardo, Dani Rodrik, and Andres Velasco. "Growth Diagnostics.” NBER Working Paper, 2005.

http://ksghome.harvard.edu/ drodrik/growth_accelerations_aug05.pdf.

Heritage Foundation. "The 2009 Index of Economic Freedom." Heritage Foundation and Wall Street Journal, 2009. http://www.heritage.org/index/.

International Monetary Fund. "IMF Data Mapper."

http://www.imf.org/external/datamapper/index.php.

Krugman, Paul and Maurice Obstfeld. International Economics: Theory and Policy, $5^{\text {th }}$ Edition. New York: Addison-Wesley, 2000.

Krueger, Anne O. "Why Trade Liberalization is Good for Growth." The Economic Development Reader. Ed. Giorgio Secondi. London: Routledge, 2008: 431-440.

Madani, Dorsati and Marcello Olarreaga. "Politically Optimal Tariffs: An application to Egypt.” World Bank Policy Working Research Paper, September 2002.

McDermott, Anthony. Egypt from Nasser to Mubarak: A Flawed Revolution. New York: Croom Helm, 1988.

Omran, Mohammed. "Privatization, State Ownership, and Bank Performance in Egypt." World Development Vol. 35, No. 4, 2007: 714-733.

Richards, Alan and John Waterbury. Political Economy of the Middle East, $3^{\text {rd }}$ Edition. Boulder: Westview Press, 2008.

Rodriquez, Francisco and Dani Rodrik, "Trade Policy and Economic Growth: A Skeptic's Guide to the Cross-National Evidence," in Ben Bernanke and Kenneth Rogoff, NBER Macroeconomics Annual 2000. Cambridge, 2001: 261-325.

Rodrik, Dani. "Trading in Illustions." The Economic Development Reader. Ed. Giorgio Secondi. London: Routledge, 2008: 458-466.

Romer, Paul. "Capital Accumulation in the Theory of Long Run Growth." in Robert Barro, ed. Modern Business Cycle Theory. Cambridge: Harvard University Press, 1989: 51-127. 


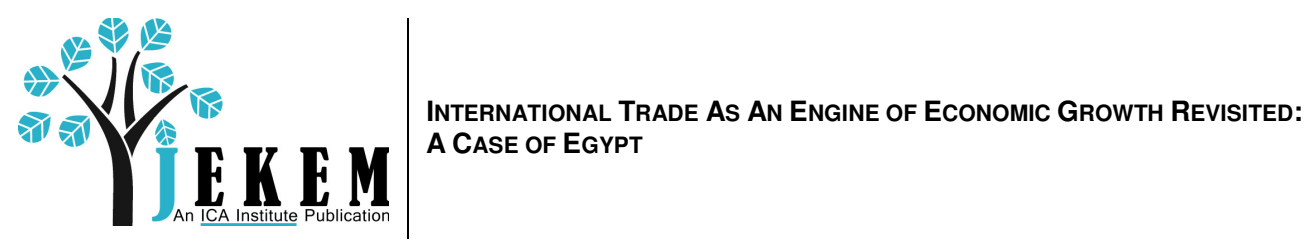

Sachs, Jeffrey and Andrew Warner. "Economic Reform and the Process of Global Integration.” Brookings Papers on Economic Activity, No. 1, 1995.

Soderling, Ludvig, "Is the Middle East and North Africa Region Achieving Its Trade Potential?" IMF Working Paper, May 2005.

Srinivasan, T.N. and Jagdish Bhagwati. "Outward-Orientation and Development: Are

Revisionists Right?” in Deepak Lal and Richard H. Snape, eds. Trade, Development and

Political Economy: Essays in Honour of Anne O. Krueger. New York: Palgrave, 2001.

Subramanian, Arvind. "The Egyptian Stabilization Experience: An Analytic Retrospective."

International Monetary Fund Working Paper, September 1997.

United States Trade Representative. "Trade Summary: Egypt." United States Trade Representative, 2005.

http://www.ustr.gov/assets/Document Library/Reports Publications/2005/2005 NTE Rep ort/asset_upload_file858_7466.pdf

United States Trade Representative. "Trade Summary: Egypt.” United States Trade Representative, 2006.

http://www.ustr.gov/assets/Document_Library/Reports_Publications/2006/2006_NTE_Rep ort/asset_upload_file102_9241.pdf 2006

United States Trade Representative. "Trade Summary: Egypt." United States Trade

Representative, 2007.

http://www.ustr.gov/assets/Document_Library/Reports_Publications/2007/2007_NTE_Rep

ort/asset_upload_file846_10941.pdf

United States Trade Representative. "Trade Summary: Egypt." United States Trade

Representative, 2008.

http://www.ustr.gov/assets/Document_Library/Reports_Publications/2008/2008_NTE_Rep ort/asset_upload_file288_14647.pdf

Waterbury, John. The Egypt of Nasser and Sadat: The Political Economy of Two Regimes. Princeton: Princeton University Press, 1983.

World Bank. "Doing Business 2007: Comparing Regulation in 181 Economies." International Bank for Reconstruction/World Bank, 2007.

http://www.doingbusiness.org/documents/DoingBusiness2007_FullReport.pdf.

World Bank. "Doing Business 2008: Comparing Regulation in 178 Economies."

International Bank for Reconstruction/World Bank, 2008.

http://www.doingbusiness.org/documents/FullReport/2008/DB08_Full_Report.pdf.

World Bank. "Doing Business 2009: Comparing Regulation in 181 Economies."

International Bank for Reconstruction/World Bank, 2009.

http://www.doingbusiness.org/Documents/FullReport/2009/DB_2009_English.pdf. 
World Bank. "Trading Across Borders Methodology."

http://www.doingbusiness.org/MethodologySurveys/TradingAcrossBorders.aspx.

WTO Secretariat. "Trade Policy Review Egypt: Report by the Secretariat." World Trade Organization WT/TPR/S/55, 18 May 1999.

WTO Secretariat. "Trade Policy Review Egypt: Report by the Secretariat." World Trade Organization WT/TRP/S/150, 28 June 2005.

Zaki, Mokhlis Y., "IMF-Supported Stabilization Programs and their Critics: Evidence from the Recent Experience of E Egypt," World Development Vol. 29, No. 11 (2001), pp. 1867-1883. 